\title{
Building Dynamic Capabilities with the Internet of Things
}

\author{
Mary Dunaway \\ Morgan State University \\ mary.dunaway@morgan.edu
}

\author{
Yulia W. Sullivan \\ Baylor University \\ yulia_sullivan@baylor.edu
}

\author{
Samuel Fosso Wamba \\ Toulouse Business School \\ fossowam@gmail.com
}

\begin{abstract}
In this study, we propose internet of things (IoT) capabilities as dynamic capabilities through their effect on a firm's competitive advantage. We argue that the importance of the IoT lies on its ability to identify new opportunities, address them, and reconfigure the existing and/or new technology assets in rapid technology change environments. Firms with strong IoT capabilities will be able to create, (re)shape, and transform their business ecosystems through innovation. Using data collected from 184 companies, the proposed framework was tested. The results show IoT capabilities, manifested in sensing, seizing, and reconfiguring capabilities, are positively associated with a firm's competitive advantage. This study can help scholars and practitioners understand the elements of the IoT that may lead to competitive advantage from the dynamic capabilities perspective.
\end{abstract}

\section{Introduction}

The Internet of Things (IoT) is yet another wave of value-chain improvements for organizations. This technology disruptor is trigging more innovation, productivity gains, and economic growth than previously realized with automation and internet [1]. Accenture estimates the IoT could add up to $\$ 14.2 \mathrm{~T}$ to the economy by 2020 [2]. The global IoT market is projected to grow from $\$ 2.99 \mathrm{~T}$ in 2014 to $\$ 8.9 \mathrm{~T}$ in 2020, attaining a $19.92 \%$ Compound Annual Growth Rate (CAGR). Companies expect their IoT investments will grow from $\$ 215 \mathrm{~B}$ in 2015 to $\$ 832 \mathrm{~B}$ in 2020 . According to the recent 2017 Gartner IoT study, gaining competitive advantage is one of the most significant benefits they expect to receive from the IoT [3]. Despite this promising forecast of the IoT, business organizations are challenged to understand how the IoT can be used to build and maintain competitive advantage. While the value and benefits that the IoT may bring to an organization are promising, companies have yet to either generate huge revenue gains or create business value, causing investment concerns [4].
The existing research on the IoT has primarily focused on developing the technical components of the IoT; overlooking the importance of understanding the IoT from the managerial perspective. Creating business value using IoT technologies is a fundamental issue since the IoT investment is extremely complex and expensive. Thus, focusing on business outcomes instead of on technology per se will be a vital requirement for the successful implementation of the IoT [5]. In other words, for the IoT to deliver its ultimate benefit-sustainable competitive advantage, companies must look beyond just the technology and address their competitive transformation in more dynamic ways to advance their strategic and operational goals.

Motivated by the need to establish the relationship between the IoT and a firm's competitive advantage, our research objective is simple: to study IoT capabilities and their role in creating competitive advantage. Drawing upon the dynamic capabilities perspective, we first examine the extent to which the IoT has the capacity to sense and shape opportunities and threats, seize opportunities, and reconfigure a firm's intangible and tangible assets. We model IoT capabilities as a source of competitive advantage. Second, we identify key measures for IoT capabilities that would lead to competitive advantage. Third, we empirically test the relationship between IoT capabilities and competitive advantage. We address the issue of the IoT at the organizational level to help provide insights and inputs to firms facing uncertainty in making decisions related to the IoT implementation.

\section{Theoretical Development}

We ground our theoretical model in the dynamic capabilities framework [6] to establish the relationship between IoT capabilities and a firm's competitive advantage. We explain how IoT-enabled sensing, seizing, and reconfiguring activities can be simultaneously developed and applied for an organization to build its competitive advantage. 


\subsection{Dynamic Capabilities}

The dynamic capabilities framework was proposed by Teece et al. [6] to "explain the sources of enterpriselevel competitive advantage over time and provide guidance to managers for avoiding the zero profit condition that results when homogenous firms compete in perfectly competitive markets." (p. 1320). Dynamic capabilities are defined as "the firm's ability to integrate, build, and reconfigure internal and external competences to address rapidly changing environments" [6]. Dynamic capabilities include difficult-to-duplicate capabilities required to adapt to changing customer and technology opportunities [7]. Dynamic capabilities differ from operational capabilities in two ways. First, whereas operational capabilities enable an organization to perform an activity on an on-going basis using the same techniques on the same capacity to serve the same customer population [8], dynamic capabilities are directed toward strategic changes and the alignment between the organization and its environment [9]. Second, dynamic capabilities require a longer-term focus than operational capabilities and they involve subordinating short-run cost cutting, optimization, and other best practices [10]. Thus, dynamic capabilities define a firm's capacity to innovate, adapt to change, and create change that is favorable to customers and unfavorable to competitors [10].

Dynamic capabilities can be disaggregated into three capabilities: (1) to sense and shape opportunities and threats, (2) to seize opportunities, and (3) redeploy and reconfigure a firms' resources [7]. Sensing and shaping new opportunities include activities, such as scanning, creation, learning, and interpretive activity. Seizing opportunities involve maintaining and improving technological competences and complementary assets [6], mobilizing resources to address needs and opportunities, and capturing value from doing so [10]. Reconfiguring tangible and intangible resources is a firm's capabilities to recombine resources and operating capabilities as the organization grows and as markets and technologies change $[7,9]$.

Dynamic capabilities have long been considered a key to competitive advantage by enabling organizations to innovate and capture sufficient value to deliver a superior performance [6, 7]. Although routines and processes are vital components of dynamic capabilities [11], we argue that technologybased competence and capabilities embedded in an organization and manifested in its employees is a source of competitive advantage. Whereas routines tend to be relatively slow to change [10], organizations with people who are adaptive to technology change will override routines. Data, information, knowledge, and capabilities enabled by technology are not only scare but also difficult to imitate as they are unique to an organization.

\subsection{Gaining Competitive Advantage through Internet of Things Capabilities}

Although firms have many IT resources, only a few of these have the potential to lead them to a position of sustained competitive advantage [12]. Competitive advantage is originated in the deployment and use of idiosyncratic, valuable, and inimitable resources and capabilities [13]. Competitive advantage accrues when "competitors face significant challenges in acquiring, developing, and using the resources underlying the value creating strategy" [14, p. 749] The dynamic capabilities framework recognizes competences and capabilities can provide competitive advantage and generate profits only if they are unique and difficult to imitate [6]. Although one can argue that IT-related capabilities are considered operational capabilities [12], our focus is not simply on the physical artifacts of the IoT which are easy to imitate, but on the configuration of an activity system that depends on the IoT technology at its core to foster the creation and appropriation of business value [14]. The IoT is expected to bridge diverse technologies to enable new applications by connecting physical objects together in support of intelligent decision making [15]. Such system is embedded, making it difficult to imitate and comparatively more valuable, and therefore, a source of competitive advantage.

According to the dynamic capability perspective, firms leverage their current asset positions to develop or renew superior capabilities that enable them to maintain competitiveness $[6,14$,$] . By drawing on the$ basic tenets of the dynamic capabilities in the form of sensing, seizing, and reconfiguring, we argue that the IoT has capabilities to open up new market opportunities, create knowledge, initiate changes, and respond to customer expectations. Although the IoT infrastructure itself will not be a major source of competitive advantage, we argue that IoT-based innovation capabilities will enable firms to generate incremental business value and thus, are a source of competitive advantage [16]. Building on the IT capabilities literature, we define IoT capabilities as $a$ unique type of IT capability that relies on the network of physical objects to sense new opportunities and treats, to move resources to address those new opportunities, and to reconfigure IT assets.

Unlike other new technologies, the characteristic of the IoT that combines the physical and digital components to create new products or services and 
enables novel business models [16] makes the IoT a value creation tool for an organization. Many of important new technologies, including cloud computing, RFID identification technology, and sensor network technology are integrated to promote the development of the IoT to a new level [17]. Whereas such new technologies, if implemented individually, will less likely to be a source of competitive advantage, their integration, complemented by a firm's resources is a source of competitive advantage because this integration makes it difficult for competitors to copy the total effect of the IoT [18]. Knowledge creation and the skills that form the IoT capabilities help decision makers make better decisions based on real-time data collected through the network of things and ultimately, lead to competitive advantage. Figure 1 illustrates our conceptual model.

Further, the IoT offers a compelling distinctive, measurable, and sustainable stakeholder value proposition for firms. As firms evaluate these aspects and engage in pragmatic steps, value points can emerge from a sustainable transformation [19, 20], which in turn will systematically offer ways to deliver favorable value proposition to a firm. For example, when geographic sensors are embedded within an IS solution to gather environmental and pollution data from shipping sources, the data can be of interest to potential customers for data analytics (e.g., monetization, government, or other uses). In this instance, data analytics can potentially create new business models. The value proposition is beyond the operational shipping data; it shapes sustainability and attracts valuable stakeholders from strategic-minded and likely C-suite (e.g. CIO, CFO, COO) decision makers.

As illustrated in Figure 1, IoT capabilities consist of all three primary activities as conceptualized in the original framework of dynamic capabilities. As a type of IT resource, the IoT by itself unlikely contributes to sustained competitive advantage. However, once the IoT is positioned as a part of a complex chain of assets and capabilities (e.g., technical skills, business understanding), it may lead to competitive advantage. This argument is consistent with the IT capability literature which is rooted in the resource-based view. The IT capability literature argues that various ITrelated resources combine to form an IT capability that is valuable, rare, non-imitable, and non-substitutable [21]. Thus, we view IoT capabilities as a collection of various IT resources and processes embedded in the network to sense key opportunities or trends, and then formulate strategies to respond to those opportunities.

Given technologies permeate every process and function of an organization, IT-related capabilities can vary, depending on how these technologies serve their purpose in an organization [22]. For example, Gold et al. [23] proposed knowledge-management capabilities to include the ability to perform specialized processes to acquire, convert, apply, and protect knowledge; Karimi et al. [24] proposed ERP capabilities to include an ERP system's range, reach, and geographic scope; Kulkarni et al.[22] developed a firm's business intelligence capability consisting of two aspects: information capability and system capability; and Akter et al. [25] theorized big data analytics capabilities as a hierarchical model consisting of three dimensions: management, technology, and talent capability.

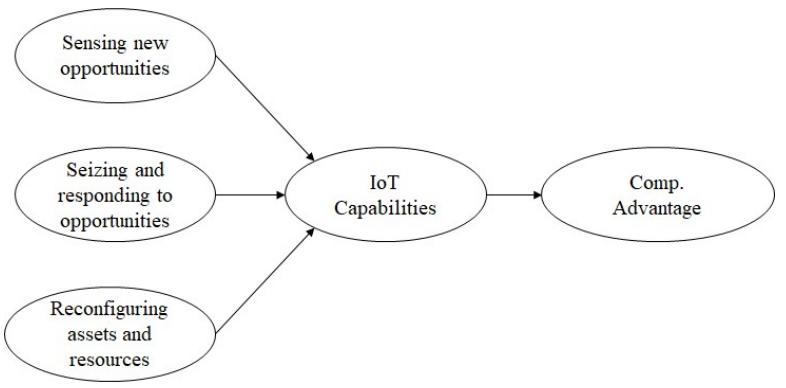

Figure 1. Conceptual Framework

Our model focuses on the IoT capabilities as distinct IT capabilities that rely on the network of physical objects (embedded with electronics, software, sensors, and network connectivity) to collect and exchange data [26]. IoT capabilities specifically center on using the real-time data generated by the IoT to create opportunities and identify innovative strategies. Unlike the traditional internet or e-commerce capabilities that focus on establishing connections between webpages or systems, the IoT requires the combination of data in which every smart object or thing in the network interacts and communicates with each other [15]. And unlike the simple automation of machinery, the IoT is also mobile and virtual, and features a continuous internet connection [27].

In the IoT environment, organizations can constantly collect and analyze data about people and their behaviors online [28]. This, in turn can be used to explore innovative ideas as well as deliver value for managerial decision making. For example, in a smart factory, the IoT can be used to build a better inventory management system, improve production processes, and increase delivery time efficiency. Sensors on the factory floor have the capability to constantly transmit data at every step of the manufacturing process to provide operators with information they need to produce a better product and ensure on-time delivery. The incoming business intelligence could even enable a company to proactively send a technician to fix a machine before it breaks down [27]. Based on the 
characteristics of the IoT, we argue that three distinct aspects of dynamic capabilities: sensing, seizing, and reconfiguring are qualitatively relevant to describe IoT capabilities. The areas of IoT capabilities are summarized in Table 1.

Table 1. Key IoT-enabled Capabilities

\begin{tabular}{|c|c|c|}
\hline $\begin{array}{l}\text { Capabi- } \\
\text { lity }\end{array}$ & $\begin{array}{c}\text { IoT-enabled } \\
\text { Activities }\end{array}$ & $\begin{array}{c}\text { Effective Use of the } \\
\text { IoT }\end{array}$ \\
\hline Sensing & $\begin{array}{l}\text { Tracking and } \\
\text { monitory system } \\
\text { Big data } \\
\text { repository } \\
\text { Advanced } \\
\text { analytics and } \\
\text { artificial } \\
\text { intelligence }\end{array}$ & $\begin{array}{l}\text { - Extracting essential } \\
\text { insights and } \\
\text { responding to } \\
\text { changing conditions } \\
\text { in-time } \\
\text { - Remotely } \\
\text { monitoring objects } \\
\text { in the network to } \\
\text { enhance productivity } \\
\text { - Harvesting } \\
\text { knowledge from a } \\
\text { large amount of data } \\
\text { - Monitoring user } \\
\text { experience using } \\
\text { devices connected } \\
\text { through the network }\end{array}$ \\
\hline Seizing & $\begin{array}{l}\text { Object-to-object } \\
\text { communication } \\
\text { Flexible resource } \\
\text { management }\end{array}$ & $\begin{array}{l}\text { - Using smart devices } \\
\text { for feedback } \\
\text { management } \\
\text { processes } \\
\text { - Cost reduction } \\
\text { through effective } \\
\text { resource allocation } \\
\text { processes } \\
\text { - Managing and } \\
\text { capturing } \\
\text { opportunities to } \\
\text { refine business } \\
\text { models } \\
\text { - Increasing decision } \\
\text { accuracy }\end{array}$ \\
\hline Reconf. & $\begin{array}{l}\text { New } \\
\text { product/service } \\
\text { development } \\
\text { Business value } \\
\text { creation }\end{array}$ & $\begin{array}{l}\text { - Generating new } \\
\text { revenues through } \\
\text { improved } \\
\text { products/services } \\
\text { - Managing strategic } \\
\text { fit to ensure IT } \\
\text { resources in the } \\
\text { network are value } \\
\text { enhancing } \\
\text { - Achieving digital } \\
\text { transformation to } \\
\text { accommodate rapid } \\
\text { changes }\end{array}$ \\
\hline
\end{tabular}

2.2.1. IoT-enabled Sensing Capability. In a hightechnology environment, companies must sense and/or generate options for growth before their competitors do [10]. The sensing activities enabled by the IoT include the ability to gather real-time data and information about what's going on the network and business ecosystems, tracking and monitoring systems, big data repository, and advanced analytics and artificial intelligence. These activities provide opportunities for an enterprise to create hypotheses about future implications based on real-time data and test these hypotheses to increase the pathways for new innovation [10]. Given the IoT allows objects or things to sense their environment [29], knowledge generated from the sensing activities is difficult to imitate; it cannot be bought and generally, it must be gathered in an environment specific to an organization. Using the IoT outputs, management can filter technology, customer, and competitive information from both inside and outside the company, making sense of it, and configuring its implications for new products, services, and business models.

2.2.2. IoT-enabled Seizing Capability. In seizing new opportunities, the IoT provides a new pathway to achieve new and innovative forms of competitive advantage. Data collected from the IoT are intangible assets that can help companies make decisions with regard to which technologies and features are to be included in current or new devices or services. These data fuel the business value and transformative nature of the IoT [5]. The IoT also enables decision makers in the organizations to use predictive analytics of big data to identify which value to be captured in the market, design or redesign cost and revenue structures, and avoid decision errors. Such managerial decisions determine how the company creates, shapes, and deploys capabilities. When this process is properly executed, it will result in innovative combinations of resources supported by profitable value-capture mechanisms, which are the sources of competitive advantage [10].

2.2.3. IoT-enabled Reconfiguring. The successful identification of opportunities, the evaluation of existing and emerging capabilities, and the possible investment in relevant designs and devices will lead to a firm's capacity to recombine computing resources [9]. The existing and new technologies (e.g., sensors, cloud, communicating technologies) can be integrated and recombined in different ways based on the characteristics and demands of the market [30].

By drawing on the three primary activities: sensing, seizing, and reconfiguring discussed above, 
organizations can utilize the IoT to gain competitive advantage. Their ability to do so will result in a combination of IT capabilities that are rare and difficult to imitate. We take an example from the Airbus case. Airbus introduced smart tools that use visual algorithms to monitor complex processes, such as precision drilling and automatic testing. Using these IoT tools, Airbus is able to deliver their airplanes faster to customers [31]. When asked about the importance of the IoT for his company's sustained competitive advantage, Airbus Vice President of product and cyber security program directorate Simon Bradley said "One of the first things the company did was to use RFID in tracking parts, and now we're moving towards IoT devices to track tools in the factory, so engineers know where their key tools are, and also the tools can be telling them if the torque is correct for implementation, and also determine if products need maintenance. So, we're looking at a whole raft of things to not only improve products but also to reduce cost and improve production capability" [32].

\section{Empirical Validation of the Conceptual Framework}

We conducted an empirical study to test the relationship between IoT capabilities and a firm's competitive advantage. We conducted a web-basedsurvey administered to IT decision makers in organizations that have adopted the IoT A professional market research company managed the survey to obtain a panel sample who were IT decision makers in roles (e.g. CIO, IT managers, project leaders) located in the US. The identities of participants were kept confidential by the market research firm.

According to the server hosting the online survey, 879 panel members accepted the invitation and, among them 819 agreed to the consent form. Participants were screened to eliminate those who worked in organizations without an IoT implementation. The types of IoT projects adopted by their organization and status were captured from the participants. Survey quotas were restricted based on the firm size, to limit the number of target respondents who could take the survey. The quota sampling was used to ensure the heterogeneity of the sample, which would likely reduce the potential bias arising from organizational factors that can be present when dealing with small numbers of underrepresented sociodemographic subgroups. Among 819 potential respondents who agreed to the consent form, 472 were eliminated because the quotas were filled. Of the remaining 347, 163 were later eliminated because of incomplete answers and unreliable responses. The final sample resulted 184 usable responses for analysis. The sample characteristics are presented in Table 2.

Table 2. Demographic Respondents

\begin{tabular}{|c|c|c|}
\hline Variable & Category & Freq. \\
\hline \multirow[t]{8}{*}{ IoT Project } & $\begin{array}{l}\text { Track and monitor } \\
\text { technology devices used } \\
\text { in your work } \\
\text { environment }\end{array}$ & $\begin{array}{l}170 \\
(92.4 \%)\end{array}$ \\
\hline & $\begin{array}{l}\text { Environmental } \\
\text { monitoring }\end{array}$ & $\begin{array}{l}159 \\
(86.4 \%)\end{array}$ \\
\hline & $\begin{array}{l}\text { Monitor customer } \\
\text { experience with } \\
\text { connected product using } \\
\text { smart devices }\end{array}$ & $\begin{array}{l}162 \\
(88.0 \%)\end{array}$ \\
\hline & $\begin{array}{l}\text { Use sensors (e.g., } \\
\text { RFID) to detect objects, } \\
\text { goods, and real-time } \\
\text { inventory information }\end{array}$ & $\begin{array}{l}147 \\
(79.9 \%)\end{array}$ \\
\hline & Use predictive analytics & $\begin{array}{l}159 \\
(86.4 \%)\end{array}$ \\
\hline & $\begin{array}{l}\text { Utilize big data for } \\
\text { performance analysis }\end{array}$ & $\begin{array}{l}166 \\
(90.2 \%)\end{array}$ \\
\hline & $\begin{array}{l}\text { Use intelligent systems } \\
\text { to control and monitor } \\
\text { business and/or } \\
\text { manufacturing } \\
\text { processes }\end{array}$ & $\begin{array}{l}166 \\
(90.2 \%)\end{array}$ \\
\hline & $\begin{array}{l}\text { Use wearable } \\
\text { technology devices to } \\
\text { monitor employees' } \\
\text { activities }\end{array}$ & $\begin{array}{l}126 \\
(68.5 \%)\end{array}$ \\
\hline \multirow{8}{*}{$\begin{array}{l}\text { Industry } \\
\text { Category }\end{array}$} & Information technology & $55(30 \%)$ \\
\hline & Information & $24(13 \%)$ \\
\hline & Manufacturing & $22(12 \%)$ \\
\hline & $\begin{array}{l}\text { Professional, scientific, } \\
\text { and technical services }\end{array}$ & $17(9.2 \%)$ \\
\hline & Finance and insurance & $13(7.1 \%)$ \\
\hline & Education and services & $12(6.5 \%)$ \\
\hline & Construction & $11(6 \%)$ \\
\hline & Other & $30(16.2 \%)$ \\
\hline \multirow{6}{*}{$\begin{array}{l}\text { Firm size } \\
\text { (number of } \\
\text { employees) }\end{array}$} & Less than 10 & $9(4.9 \%)$ \\
\hline & $10-49$ & $11(6 \%)$ \\
\hline & $50-249$ & $24(13 \%)$ \\
\hline & $250-499$ & $36(19.6 \%)$ \\
\hline & $500-999$ & $42(33.7 \%)$ \\
\hline & More than 1000 & $62(33.7 \%)$ \\
\hline \multirow{6}{*}{$\begin{array}{l}\text { Company } \\
\text { age }\end{array}$} & $1-4$ years & $5(2.7 \%)$ \\
\hline & $5-9$ years & $21(11.4 \%)$ \\
\hline & 10-14 years & $33(17.9 \%)$ \\
\hline & $15-19$ years & $32(17.4 \%)$ \\
\hline & 20-24 years & $30(16.3 \%)$ \\
\hline & Over 25 years & $63(34.0 \%)$ \\
\hline Respondents' & IT managers & $83(45.1 \%)$ \\
\hline
\end{tabular}




\begin{tabular}{|l|l|l|}
\hline Variable & \multicolumn{1}{|c|}{ Category } & \multicolumn{1}{c|}{ Freq. } \\
\hline \multirow{3}{*}{$\begin{array}{c}\text { managerial } \\
\text { position }\end{array}$} & CIO & $27(14.7 \%)$ \\
\cline { 2 - 3 } & CEO & $17(9.2 \%)$ \\
\cline { 2 - 3 } & Business/system analyst & $14(7.6 \%)$ \\
\cline { 2 - 3 } & IT project leader & $10(5.4 \%)$ \\
\cline { 2 - 3 } & IT architect & $10(5.4 \%)$ \\
\cline { 2 - 3 } & $\begin{array}{l}\text { Other (e.g., business } \\
\text { manager) }\end{array}$ & $23(12.5 \%)$ \\
\hline
\end{tabular}

\subsection{Scale Development}

Whenever possible, measurement items were adapted from existing scales. All measurement items were measured at the organizational level. IoT capabilities is measured as a formative latent construct consisting of three dimensions - sensing, seizing, and reconfiguring. A formative model is deemed appropriate since the three areas of IoT capabilities define or form the second order overall IoT capabilities. These three areas are also complementary to each other and they cumulatively combine to serve the overall purpose of IoT capabilities [21]. Sensing capabilities were measured using six items adapted from Pavlou and El Sawy's [21, 33] instruments on new product development sensing capabilities. To measure seizing capabilities, we developed three new items by adapting Wilden et al.'s [9] instruments. These items specifically capture the effective selection of new opportunities or innovative ideas and responsiveness to the IoT outputs. Reconfiguration was measured using three items adapted from Pavlou and El Sawy's [21] instruments. To measure competitive advantage, we used two items from [33].

Measurement items used in the current study are presented in the Table 3 . As is common in the organizational level research, the survey instructions asked the IT decision makers (e.g., CIO, IT managers, IT project leaders) to respond based on their selfjudgement about IoT practices in their organization (relative to their competitors). All items were measured on a seven-point Likert scale. Several firms' characteristics (i.e., firm size, business category whether it's an IT firm versus non-IT firm) have been shown to be related to firm performance. Thus, their effects on firm performance are controlled.

Table 3. Measurement Items, Composite Reliability, Average Variance Extracted, and Item Loadings

\begin{tabular}{|l|l|l|l|}
\hline Construct & \multicolumn{1}{|c|}{ Item } & $\begin{array}{c}\text { CR, } \\
\text { AVE }\end{array}$ & $\begin{array}{l}\text { Loa- } \\
\text { ding }\end{array}$ \\
\hline Sensing & $\begin{array}{l}\text { [In my organization,] IoT } \\
\text { practices are frequently } \\
\text { used to scan the } \\
\text { environment to identify }\end{array}$ & $\begin{array}{l}.951 \\
(.762)\end{array}$ & .868 \\
\hline
\end{tabular}

\begin{tabular}{|c|c|c|c|}
\hline Construct & Item & $\begin{array}{c}\text { CR, } \\
\text { AVE }\end{array}$ & $\begin{array}{l}\text { Loa- } \\
\text { ding }\end{array}$ \\
\hline & $\begin{array}{l}\text { opportunity for } \\
\text { innovation. }\end{array}$ & & \\
\hline & $\begin{array}{l}\text { IoT practices are } \\
\text { constantly employed to } \\
\text { identify the likely effect } \\
\text { of changes in our business } \\
\text { environment on } \\
\text { innovation. }\end{array}$ & & .878 \\
\hline & $\begin{array}{l}\text { IoT practices are often put } \\
\text { in place to ensure our } \\
\text { innovative strategies are } \\
\text { in line with our needs. }\end{array}$ & & .873 \\
\hline & $\begin{array}{l}\text { IoT practices are } \\
\text { implemented extensively } \\
\text { to improve our ideas for } \\
\text { innovation. }\end{array}$ & & .893 \\
\hline & $\begin{array}{l}\text { IoT practices are effective } \\
\text { in identifying new } \\
\text { innovative ideas. }\end{array}$ & & .880 \\
\hline & $\begin{array}{l}\text { IoT practices enable us to } \\
\text { quickly respond to } \\
\text { significant changes in our } \\
\text { business needs. }\end{array}$ & & .845 \\
\hline \multirow[t]{4}{*}{ Seizing } & $\begin{array}{l}\text { We invest in the IoT } \\
\text { projects to find new } \\
\text { innovative ideas. }\end{array}$ & \multirow[t]{4}{*}{$\begin{array}{l}.929 \\
(.766)\end{array}$} & .866 \\
\hline & $\begin{array}{l}\text { IoT practices are used to } \\
\text { select the best innovative } \\
\text { ideas for further detailing. }\end{array}$ & & .895 \\
\hline & $\begin{array}{l}\text { We respond to problems } \\
\text { and/or issues identified } \\
\text { through predictive } \\
\text { analysis of big data. }\end{array}$ & & .878 \\
\hline & $\begin{array}{l}\text { We change our practices } \\
\text { when data gathered from } \\
\text { the IoT give us a reason to } \\
\text { change. }\end{array}$ & & .862 \\
\hline \multirow[t]{3}{*}{ Reconf. } & $\begin{array}{l}\text { Technology devices, } \\
\text { networks, and people are } \\
\text { well organized in our } \\
\text { working environment. }\end{array}$ & \multirow[t]{3}{*}{$\begin{array}{l}.873 \\
(.696)\end{array}$} & .776 \\
\hline & $\begin{array}{l}\text { The output of our IoT } \\
\text { practices enable us to } \\
\text { appropriately allocate the } \\
\text { resources (i.e., } \\
\text { information, time, reports) } \\
\text { within our firm. }\end{array}$ & & .866 \\
\hline & $\begin{array}{l}\text { IoT practices enable us to } \\
\text { coordinate the } \\
\text { compatibility between } \\
\text { tasks, people, and } \\
\text { technology. }\end{array}$ & & .859 \\
\hline
\end{tabular}




\begin{tabular}{|l|l|l|l|}
\hline Construct & \multicolumn{1}{|c|}{ Item } & $\begin{array}{c}\text { CR, } \\
\text { AVE }\end{array}$ & $\begin{array}{l}\text { Loa- } \\
\text { ding }\end{array}$ \\
\hline $\begin{array}{l}\text { Comp. } \\
\text { Advantage }\end{array}$ & $\begin{array}{l}\text { In the past year, we have } \\
\text { gained strategic } \\
\text { advantages in the industry } \\
\text { over our competitors. }\end{array}$ & $\begin{array}{l}.948 \\
\text { In the past year, we have } \\
\text { gained a competitive } \\
\text { advantage over our } \\
\text { competitors. }\end{array}$ & .952 \\
\cline { 2 - 3 } & & .946 \\
\hline
\end{tabular}

\subsection{Assessment of Measurement Validity}

The measurement and structural model were tested using Partial Least Squares-Structural Equation Model (PLS-SEM). The PLS-SEM is deemed appropriate for the study because of the existence of a second-order formative construct. SmartPLS (version 3.2.7) [34] was used for the estimations. We first assessed the psychometric properties of all the reflectively measured scales using guidelines suggested by Fornell and Larcker [35]. Composite reliability scores for the final measured scales ranged from .87 to .94 , exceeding .707 recommended guidelines (see Table 3 ).

To ensure the discriminant validity of the principal constructs, the square root of the average variance extracted (AVE) for each construct was compared with the other correlation scores in the correlation matrix. As seen in Table 4, the square root of the AVE for each construct exceeds the construct's correlations with other constructs. Further the confirmatory factor analysis shows that all of the measurement item loadings on the intended constructs were above .707 and were at least .10 less on their loading on other constructs [36].

Table 4. Correlation Matrix

\begin{tabular}{|c|l|c|c|c|c|c|}
\cline { 2 - 7 } \multicolumn{1}{c|}{} & Construct & $\mathbf{1}$ & $\mathbf{2}$ & $\mathbf{3}$ & $\mathbf{4}$ & $\mathbf{5}$ \\
\hline $\mathbf{1 .}$ & Sensing & $\mathbf{. 8 7 3}$ & & & & \\
\hline $\mathbf{2 .}$ & Seizing & .727 & $\mathbf{. 8 7 5}$ & & & \\
\hline $\mathbf{3 .}$ & Reconf & .705 & .732 & $\mathbf{. 8 3 4}$ & & \\
\hline $\mathbf{4 .}$ & IoT Cap. & - & - & - & - & \\
\hline $\mathbf{5 .}$ & CA & .617 & .600 & .582 & .664 & $\mathbf{. 9 4 9}$ \\
\hline
\end{tabular}

Note: CA: Competitive Advantage; IoT Cap. is a second order formative construct formed by weighted sums of their first order constructs (sensing, seizing, and reconfiguring).

\subsection{Testing the Relationship between IoT Capabilities and Competitive Advantage}

To test the structural model, we used SmartPLS version 3.2.7. The formative construct IoT capabilities was formed by generating factor scores for each of its first-order dimensions see [37] for details). We assessed the possibility of multicollinearity across the formative indicators of the IoT capability construct. Variance inflation factor (VIF) values for the formative indictors ranged from 2.17 to 3.21 . There values were below the threshold of 3.3 [38], indicating multicollinearity is not a major issue.

The results of the structural model are illustrated in Figure 2. Since we conceptualized IoT capabilities as a second-order formative construct formed by sensing, seizing, and reconfiguring capabilities, we looked at the weights of these capabilities. Given the three dimensions of IoT capabilities are correlated, we mapped the IoT capabilities construct to Model $A$ estimation in PLS (see Becker et al. [39] for details). We found that the weight coefficients are significant, suggesting that each capability significantly contributes to the underlying overall factor. None of the control variable were significant; thus, they were eliminated from the final model. As we predicted, IoT capabilities positively affects competitive advantage $(\beta=.664, \rho<$ $.001)$. These results find support for the effect of IoT capabilities on competitive advantage $\left(\mathrm{R}^{2}=.44\right)$.

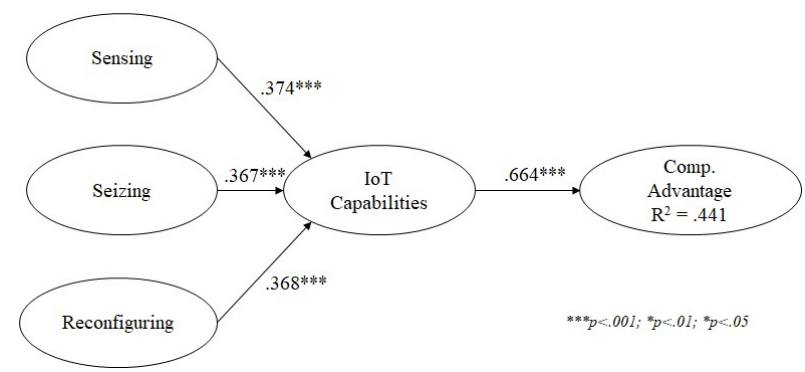

Figure 2. Empirical Model

\section{Discussion and Conclusions}

The aim of this study was to explore organizational IoT capabilities and its role in creating competitive advantage. We believe our work is a timely attempt to assess the organizational capabilities attributed to a specific type of technology disruptor. The IoT dynamic capabilities framework is conceptualized as sensing, seizing, and reconfiguring. We leveraged a structural model for the areas and theorized the organizational conditions that stimulate the dynamic capabilities leading to competitive advantage. We believe our work provides a strong directive of how IoT capabilities play a role in a firm's competitive advantage. As other dynamic capabilities, the IoT capabilities enable firms to "integrate, build, and reconfigure internal and external competencies to address rapidly-changing environment" [6, p. 517].

The study yields three implications for theory and research. First, we conceptualize and measure the construct of IoT capabilities. For decades, IS researchers and practitioners have been challenged to 
explain the strategic roles of IT. At the same time, business organizations have been trying to understand how the IoT can create value as this new phenomenon requires them to incorporate computational capabilities differently in their business operations. To address these issues, we proposed a construct called IoT capabilities. This construct draws on the dynamic capabilities literature, but it takes into considerations the unique characteristics of the IoT as a network of physical objects (e.g., devices, software, sensors, etc.) that enables them to collect and exchange data. As noted by [40], the strength of a firm's dynamic capabilities is crucial in many ways to its ability to improve its profitability in the long term. Because the IoT is just like the internet that can be adopted by any firms, focusing on IoT capabilities to capture, sense, seize, modify, and reconfigure a firm's competence is what can differentiate a firm from its competitors.

Prior research has suggested firms' competitive advantage lasts for a short period of time [41]. Although, it is expected dynamic capabilities are developed to realize strategic advantages, their "development does not ensure organizational success" [42]. Consequently, the performance of dynamic capabilities should be evaluated to advance sustained competitive advantage.

Smart, connected products and devices are dramatically changing opportunities for value creation in firms. The IoT is a disruptive technology-its capabilities raise real competitive challenges and are poised to enable economic gains. The exponential opportunities embedded in smart connect products brings about a huge expansion in innovation. The nature of a firms' value chain will be reshaped forcing organizations to rethink and retool their processes.

However, competition and competitive advantage continues to remain the same. Consequently, a firms' ability to sense, seize, and reconfigure within the boundaries of competition is important. The trajectory of the IoT is rapidly changing how value is created, competition is sustained, and the competition boundaries itself. The IoT provides firms the change agent to aggressively embrace opportunity and invigorate as a technology leader in the global economy.

Our study's primary limitation is the use of crosssectional data. Although the study's cross-sectional design did not allow us to test the longitudinal impact of IoT capabilities, our study provides a solid crosssectional model that can be used as a foundation for future research intended to establish the causality between IoT capabilities and competitive advantage. Further, we only use a single key informant (senior IT decision makers) to evaluate the organization's IoT capabilities. Although this practice is not uncommon in the organizational research, it still subjects to common method bias. We performed multiple tests (e.g., Harman's one-factor test, latent method construct) to confirm that common method bias is not an issue. Although all these tests confirmed that the results do not suffer from common method bias, there is still a possibility that this bias would have increased all the interrelationships among the principal constructs in the study. Future research could recruit multiple key informants in the organizations across different periods of time to minimize this bias.

Overall, our results confirm that sensing, seizing, and reconfiguration strongly create dynamic capabilities from IoT technology. The IoT capabilities in turn advance sustained competitive advantage. This valuable insight sheds light into how the IoT enhances a firms' ability to adapt and create value from a strategic change agent. The value-add derived from the IoT outputs can bring about a new set of resources to sustain or enhance the firms' competitive advantage. IT decision makers are encouraged to adopt the IoT in their organizations not merely because their competitors have adopted them. Rather, they must pay attention to optimizing dynamic capabilities of the IoT while being responsive to the rivals' competitive actions. Taking these factors into consideration, IT managers will be able to improve a firm's ability to compete with its rivals when leveraging IoT capabilities.

\section{References}

[1] Porter, M. E. and Heppelmann, J. E. "How Smart Connected Products Are Transforming Competition", Harvard Business Review, 92(11), 2014, pp. 65-87.

[2] Columbus, L. (2016, November 27). Roundup of Internet of Things Forecasts and Market Estimates, 2016. Retrieved January $\quad 01, \quad 2018, \quad$ from https://www.forbes.com/sites/louiscolumbus/2016/11/27/rou ndup-of-internet-of-things-forecasts-and-market-estimates2016/\#4e15cd77292d

[3] Gartner. "Business Benefits of the Internet of Things: A Gartner Trend Insight Report," Gartner, September 22 ${ }^{\text {nd }}$ 2017.

[4] Gartner. "Securing the Internet of Things", Gartner, September $13^{\text {th }} 2017$.

[5] Gartner. "Survey Analysis: CIOs Must Be Fully Aligned with the Business to Maximize IoT Success", April $27^{\text {th }}$ 2017.

[6] Teece, D. J., Pisano, G., Shuen, A. "Dynamic Capabilities and Strategic Management", Strategic Management Journal, 18(7), 1997, pp. 509-533. 
[7] Teece, D. J. "Explicating Dynamic Capabilities: The Nature and Microfoundations of (Sustainable) Enterprise Performance", Strategic Management Journal, 28(13), 2007, pp. 1319-1350.

[8] Helfat, C. E. and Winter, S. G. "Untangling Dynamic and Operational Capabilities: Strategy for the (N) Ever-changing World", Strategic Management Journal, 32(11), 2011, pp. $1243-1250$

[9] Wilden, R., Gudergan, S. P., Nielsen, B. B., and Lings, I., "Dynamic Capabilities and Performance: Strategy, Structure and Environment", Long Range Planning, 46(1-2), 2013, pp. 72-96.

[10] Teece, D., Peteraf, M., and Leih, S. "Dynamic Capabilities and Organizational Agility: Risk, Uncertainty, and Strategy in the Innovation Economy", California Management Review, 58(4), 2016, pp. 13-35.

[11] Winter, S. G., "Understanding Dynamic Capabilities", Strategic Management Journal, 24(10), 2003, pp. 991-995.

[12] Wade, M. and Hulland, J. "Review: The Resource-based View and Information Systems Research: Review, Extension, and Suggestions for Future Research", MIS Quarterly, 28(1), 2004, pp. 107-142.

[13] Bhatt, G. D., and Grover, V., "Types of Information Technology Capabilities and Their Role in Competitive Advantage: An Empirical Study", Journal of management information systems, 22(2), 2005, pp. 253-277.

[14] Piccoli, G., and Ives, B., "IT-dependent Strategic Initiatives and Sustained Competitive Advantage: A Review and Synthesis of the Literature", MIS quarterly, 29(4), 2005, pp. 747-776.

[15] Al-Fuqaha, A., Guizani, M., Mohammadi, M., Aledhari, M., and Ayyash, M., "Internet of Things: A Survey on Enabling Technologies, Protocols, and Applications", IEEE Communications Surveys \& Tutorials, 17(4), 2015, pp. $2347-$ 2376.

[16] Wortmann, F., and Flüchter, K., "Internet of Things", Business \& Information Systems Engineering, 57(3), 2015, pp. 221-224.

[17] Li, T., Liu, Y., Tian, Y., Shen, S., and Mao, W., "A Storage Solution for Massive IoT Data Based on NoSQL", In Green Computing and Communications (GreenCom), 2012, IEEE International Conference on pp. 50-57.

[18] Kettinger, W. J., Grover, V., Guha, S., and Segars, A. H., "Strategic Information Systems Revisited: A Study in Sustainability and Performance", MIS Quarterly, 18(1), 1994, pp. 31-58.

[19] Hudson, D. "Value Propositions for the Internet of Things: Guidance for Entrepreneurs Selling to Enterprises",
Technology Innovation Management Review, 7(11), 2017, pp. 5-11.

[20] Anderson, J.C, Narus, J. A. and Rossum Van, W. "Customer Value Proposition in Business Markets", Harvard Business Review, 83(3), 2006, pp. 90 - 99.

[21] Pavlou, P. A. and El Sawy, O. A. "From IT Leveraging Competence to Competitive Advantage in Turbulent Environments: The Case of New Product Development", Information Systems Research, 17(3), 2006, pp. 198-227.

[22] Kulkarni, U. R., Robles-Flores, J. A., and Popovic, A. "Business Intelligence Capability: The Effect of Top Management and the Mediating Roles of User Participation and Analytical Decision Making Orientation", Journal of the Association for Information Systems, 18(7), 2016, pp. 516541.

[23] Gold, A. H., Malhotra, A., and Segars, A. H. "Knowledge Management: An Organizational Capabilities Perspective", Journal of Management Information Systems, 18(1), 2001, pp. 185-214.

[24] Karimi, J., Somers, T. M., and Bhattacherjee, A. "The Role of Information Systems Resources in ERP Capability Building and Business Process Outcomes", Journal of Management Information Systems, 24(2), 2007, pp. 221-260.

[25] Akter, S., Wamba, S. F., Gunasekaran, A., Dubey, R., and Childe, S. J. "How to improve Firm Performance Using Big Data Analytics Capability and Business Strategy Alignment?", International Journal of Production Economics, 182, 2016, pp. 113-131.

[26] Ives, B., Rodriguez, J. A., and Palese, B. "Enhancing Customer Service through the Internet of Things and Digital Data Streams", MIS Quarterly Executive, 15(4), 2016, pp. 279-297.

[27] Knowledge Wharton, "Leveraging the Internet of Things for Competitive Advantage", University of Pennsylvania, 2016, Retrieved from http://knowledge.wharton.upenn.edu/article/leveraging-theinternet-of-things-for-competitive-advantage/

[28] CACM Staff, "The Internet of Things," Communication of the ACM, 16(5), 2017, pp. 18-19.

[29] Whitmore, A., Agarwal, A., and $\mathrm{Xu}$, L. Da., "The Internet of Things-A Survey of Topics and Trends", Information Systems Frontier, 17(2), 2015, pp. 261-274.

[30] Perera, C. "Context Aware Computing for the Internet of Things: A Survey", IEEE Communications Surveys and Tutorials, 16(1), 2014, pp. 414-454.

[31] Young, S. "11 Amazing Success Stories to Prove that Internet of Things (IoT) is Not Just a Verbal Tic", June $9^{\text {th }}$, 2016. Available Online at 
https://www.linkedin.com/pulse/11-amazing-success-storiesprove-internet-things-iot-just-sambhani.

[32] Internet of Business. "How IoT is Helping Airbus to Make Better Planes - and Bigger Revenues", August $26^{\text {th }}$ 2016, Available Online at https://internetofbusiness.com/iothelping-airbus-make-planes-better/

[33] Pavlou, P. A., and El Sawy, O. A. "Understanding the Elusive Black Box of Dynamic Capabilities", Decision Sciences, 42(1), 2011, pp. 239-273.

[34] Ringle, C. M., Wende, S., and Becker, J.-M. (2015). "SmartPLS 3." Boenningstedt: SmartPLS GmbH, http://www.smartpls.com.

[35] Fornell, C., and Larcker, D. F. "Evaluating Structural Equations Models with Unobservable Variables and Measurement Error", Journal of Marketing Research, 18(1), 1981, pp. 39-50.

[36] Gefen, D. and Straub, D. "A Practical Guide to Factorial Validity Using PLS-Graph: Tutorial and Annotated Example", Communications of the Association for Information Systems, 16(1), 2005, pp. 91-109.
[37] Polites, G. L. and Karahanna, E. "Shackled to the Status Quo: The Inhibiting Effects of Incumbent System Habit, Switching Costs, and Inertia on New System Acceptance", MIS Quarterly, 36(1), 2012, pp. 21-42.

[38] Petter, S., Straub, D., and Rai, A. "Specifying Formative Constructs in Information Systems Research", MIS Quarterly, 31(4), 2007, pp. 623-656.

[39] Becker, J. M., Rai, A., Ringle, C. M., \& Völckner, F., "Discovering Unobserved Heterogeneity in Structural Equation Models to Avert Validity Threats", MIS Quarterly, 37(3), 2013, pp. 665-694.

[40] Teece, D. J. "Business Models and Dynamic Capabilities”, Long Range Planning, 51(1), 2018, pp. 40-49.

[41] Barney, J. "Firm Resources and Sustained Competitive Advantage", Journal of Management, 17(1), 1991, pp. 99120.

[42] Zahra, Shaker A., Harry J. Sapienza and Davidsson, P. "Entrepreneurship and Dynamic Capabilities: A Review, Model and Research Agenda," Journal of Management Studies, 43(4), 2006, pp. 917-955. 